\title{
Situational analysis of SMEs in Reynosa and Río Bravo
}

\section{Análisis situacional de las MSMEs en Reynosa y Río Bravo}

MÁRQUEZ-CHÁVEZ, Nancy Yadira, ROJAS-MONTAÑEZ, Susana, SÁNCHEZ-RAMOS, Rosalinda and VÁSQUEZ-SERRANO, Ricardo Javier

Universidad Tecnológica de Tamaulipas Norte

ID $1^{\text {st }}$ Author: Nancy Yadira, Márquez-Chávez / ORC ID: 0000-0002-7083-5367

ID $1^{\text {st }}$ Coauthor: Susana, Rojas-Montañez / ORC ID: 0000-0001-9826-3594

ID $2^{\text {nd }}$ Coauthor: Rosalinda, Sánchez-Ramos

ID $3^{\text {rd }}$ Coauthor: Ricardo Javier, Vásquez-Serrano

DOI: $10.35429 / J H R T .2019 .15 .5 .25 .30$

Received: March 30, 2019; Accepted: June 20, 2019

\section{Abstract}

This research attempted to detect factors that are avoiding business success of micro, small and medium enterprises (MIPyMES) in Reynosa and Rio Bravo, Tamaulipas, Mexico. The purpose of this analysis is to provide a business plan to the entrepreneurs based on their strengths, weaknesses, opportunities and threats which uncover their inner business administration. The study examined 81 private MIPyMES, which showed 46 strength variables, 26 opportunity variables, 30 weakness variables and 30 threat variables. The business plan provided can hence and increase their strengths and reduce the risk of uncertain decisions.

Business plan, Strength, Weakness, Opportunity and threat

\begin{abstract}
Resumen
Esta investigación intentó detectar factores que evitan el éxito empresarial de las micro, pequeñas y medianas empresas (MIPyMES) en Reynosa y Río Bravo, Tamaulipas, México. El propósito de este análisis es proporcionar un plan de negocios a los empresarios basado en sus fortalezas, debilidades, oportunidades y amenazas que descubren su administración comercial interna. El estudio examinó 81 MIPyMES privados, que mostraron 46 variables de fortaleza, 26 variables de oportunidad, 30 variables de debilidad y 30 variables de amenaza. El plan de negocios proporcionado puede, por lo tanto, aumentar sus fortalezas y reducir el riesgo de decisiones inciertas.
\end{abstract}

Plan de negocio, Fortaleza, Febilidad, Oportunidad y Amenaza

Citation: MÁRQUEZ-CHÁVEZ, Nancy Yadira, ROJAS-MONTAÑEZ, Susana, SÁNCHEZ-RAMOS, Rosalinda and VÁSQUEZ-SERRANO, Ricardo Javier. Situational analysis of SMEs in Reynosa and Río Bravo. Journal of Human Resources Training. 2019, 5-15: 25-30

$\dagger$ Researcher contributing first Author 


\section{Objective}

Apply the SWOT diagnostic tool to know in a representative way the situation of micro, small and medium enterprises and the factors that limit their growth and economic development during the months May-December 2018, divided into two periods in the cities of Reynosa and Rio Bravo from the state of Tamaulipas, with the purpose of supporting entrepreneurs in the region with a business plan that allows them to efficiently manage their resources.

\section{Hypothesis}

Most companies, particularly in the region, consider that their areas of opportunity are due to a lack of resources, when in reality MSMEs are not even able to clearly identify their weaknesses and threats due to lack of training and consultancy. Even before the company receives the financing, it is necessary to assess what it wants to apply the resource and how it intends to do so.

\section{Justification}

\section{a. Practical value:}

Microentrepreneurs in the region lack knowledge of strategic planning that allows them to identify their areas of opportunity to generate strategies and obtain more profits to ensure that their life time is prolonged. Neither companies solve their problems with more money nor can they consolidate their position. An alternative is to grow with financing, first, to ensure that there will be an environment that significantly reduces as much as possible, factors that can be adverse to it. Even with the support of the Development Bank, financing, even with soft rates, there is a risk of default. Recent experiences in other parts of the world, and even in Mexico, indicate that financing must be covered with services that take away risks from companies. Without enough "clothing", MSMEs are more likely to complicate their situation rather than resolve it. At a very high percentage, studies carried out in the country by academic organizations (Tecnológico de Monterrey, Universidad de las Américas cite two examples) indicate that MSMEs are not even able to distinguish clearly what their problems or areas of opportunity are.
This article will help to know the current situation of MSMEs to design strategies, implement corrective or preventive actions, as the case may be, that strengthen their growth and contribute to job creation, economic development and participation in binational trade. considering the geographical location. With this in a representative way the Region, the State and the Country benefit.

\section{b. Theoretical value:}

This article helps to understand the reasons for the decrease in MSMEs in the region in recent years, which are the speed of growth and scalability, the need for low interest credit, difficulty in developing strategic plans and executing them, shortage of investment in technology and talent, among others (Arana, 2018)

\section{c. The methodological value:}

It helps to create analysis on MSMEs to detect their business situation and how they are facing the new challenges for their growth, with the objective of defining the factors that slow their development and can generate solution strategies that allow them to prepare for new scenarios and acquire knowledge and experiences.

\section{Theoretical framework}

Since the last decade he has referred to different economic scenarios in which emerging countries, developing countries and major economic powers participate, both in Latin America and in the rest of the world have changed trade challenges as a result of globalization, of agreement with Hernández (2007) China could become the world's first economy by 2020 , which allows us to reflect on why Mexico, although it is located in a strategic geographical position with departures to the Atlantic and Pacific and a series of trade agreements with different countries; Why the slow growth of MSMEs?

There are many variables that may be interacting against MSMEs in our country and that do not have the expected growth and development. In Reynosa life expectancy is 5.9 years according to INEGI. (INEGI, 2016). Among the most visualized features presented by these companies are the following: 
1. Serve a limited market or, within a wider market, a small number of customers.

2. The size of these companies corresponds to the production program of each of them and to the ability of the entrepreneurs to manage it.

3. Manufacture products, with a tendency to some specialization and use simple manufacturing processes.

4. Have limited financial means.

5. Its production equipment and machinery are simple.

6. Have reduced staff.

7. Use easily accessible local raw materials, not always conservable, or semifinished.

8. Entrepreneurs personally cooperate in production, supervise it directly, or direct it through a small number of supervisors.

9. Entrepreneurs personally supervise the sales of their products.

10. Its accounting and control systems are simple.

According to Victor Manuel López Ayala the following characteristics are found:

a)

Lack of trained personnel, since the owner does everything or thinks he has the knowledge to do it, such as the use and management of inventories, purchases, sales that are normally recorded by hand; Normally in MSMEs it is the lack of knowledge since there is a resistance to change, to the use of new technologies that facilitate transactions.

b) Lack of technology Normally the owner of an SME believes that he can do everything manually and even lacks technology (hardware and software) that makes his administration efficient and therefore we not only see the MSMEs as a resistance to change, but rather we can see it as an economic aspect since, from a general perspective, MSMEs do not have enough capital to invest in technological tools. It is there where the entrepreneur can go to the government to request financial support and expand the business. c)

\begin{abstract}
Proper Accounting, since SMEs or their caretaker says that he keeps accounting as his parents do or as his grandparents did that even in a notebook they only have their entrances and exits, however, we can find that the technologies do not they only serve us to chat but we can use software, which allow us or facilitate accounting operations, without having to use an accountant.
\end{abstract}

d) Lack of distribution of their goods and services, since they encounter the problem that transport can cause them great costs and their products become more expensive, making them less competitive with the large companies that today have a distribution system automated and that makes the costs lower, as well as the prices of the products we can use, in this sense we can consider that in SMEs we can not only make customers go to SMEs to be able to obtain the service they offer, today in day with the growth of social networks, there may be other forms of marketing such as through digital platforms, or even through Networking, since we can use these means so that products can be delivered to customers. (Ayala, 2018)

\section{El impacto de la globalización en las SMEs.}

Globalization, the administration or valuation of knowledge and the permanent change of context, force us to change our paradigms. In the administration it is not the exception, since one of the most important challenges is human resources since in a globalized world it is based on the premise that man is highly substitutable in the gear of the company, leaving behind the importance or Essential Human Development for the achievement of an organization.

One of the challenges when using the terms of human resources, people are categorized as a means to achieve a specific goal, without taking into account that this must be the most important capital of our organization, since it has characteristics that will allow oxygenate it (Chiavenato, 2017). 
The Human Resources Department, as it is currently understood, is that in some companies the human capital department is a relatively new concept that does not emerge completely until the mid-2000s; its appearance is not really more than the result of a progressive transformation of the personnel function, which has been influenced by the development in thinking about people and organizations during the second half of the twentieth century (Aragon, 2017). (Ayala, 2018)

\section{Presentation of the proposal with their respective results}

Based on the SWOT diagnostic tool, 81 MSMEs were analyzed to know their strengths, opportunities, weaknesses and threats from the municipalities of Reynosa and Río Bravo. The data collected are shown in tables 1 to 4 .

As well as, the 5 variables that represent the most impact are shown in 8 graphs.

They are detailed in 2 periods of MayAugust 2018 with 34 companies and SeptemberDecember 2018 with 47 companies.

In the strengths, 46 variables shown in table 1 were detected.

The 5 variables with the most impact in both periods are detailed below:

From the May-August 2018 period they are:
a) Quality products and / or services,
b) Excellent service,
c) Adequate facilities,
d) Accessible prices,
e) Good ubication.

See graphic 1. From the SeptemberDecember 2018 period they are:
a) Excellent service,
b) Quality products and / or services,
c) Good ubication,
d) Accessible prices and
e) Schedule availability.

See graphic 2.

These strengths are what allow MSMEs to survive the challenges of their limitations.
The following table lists the 46 strength variables that were detected in the analysis.

\begin{tabular}{|r|l|}
\hline 1 & Excellent service \\
\hline 2 & Quality products and / or services \\
\hline 3 & Accessible prices \\
\hline 4 & Good ubication \\
\hline 5 & Variety of products and / or services available \\
\hline 6 & Adequate facilities \\
\hline 7 & Schedule availability \\
\hline 8 & Trained staff \\
\hline 9 & Experience with products and / or services \\
\hline 10 & Good working environment \\
\hline 11 & Market knowledge \\
\hline 12 & Good administration \\
\hline 13 & Own premises \\
\hline 14 & Product promotions \\
\hline 15 & Committed and / or motivated staff. Teamwork \\
\hline 16 & Adequate technology \\
\hline 17 & Quality raw material AND / or quality tool. \\
\hline 18 & Home service \\
\hline 19 & Internet pages (eg Facebook page), for advertising \\
\hline 20 & It has advertising campaigns \\
\hline 21 & Basic product in the basic basket \\
\hline 22 & Family business \\
\hline 23 & Product innovation \\
\hline 24 & Customer Loyalty \\
\hline 25 & Provide customized products \\
\hline 26 & Sales and purchases on credit \\
\hline 27 & Fast service \\
\hline 28 & Prestige \\
\hline 29 & Safety equipment \\
\hline 30 & Enough human capital \\
\hline 31 & Customer Security \\
\hline 32 & Trusted suppliers \\
\hline 33 & Wholesale and retail prices \\
\hline 34 & There is no exclusivity with suppliers \\
\hline 35 & There is NO near competition \\
\hline 36 & Internet for customers \\
\hline 37 & Free freight \\
\hline 38 & Excellent inventory control \\
\hline 39 & Immediate product availability \\
\hline 40 & Original Designs \\
\hline 41 & It has a bank terminal \\
\hline 43 & Client Portfolio \\
\hline
\end{tabular}

Table 1 Variables detected in strengths

In Opportunities 26 variables were detected that are shown in table 2.

The 5 variables with the most impact in both periods are detailed below:

From the period May-August 2018:
a) Market,
b) Faithful clients,
c) Demand for the product or service,
d) Suppliers,
e) Government support. 
See graphic 3.

From the period September-December 2018:
a) Market,
b) Seasonal sales,
c) Faithful clients,
d) New tendencies,
e) Demand.

See graphic 4.

Las opportunities that were detected serve as a basis for MSMEs, seek training and consulting and are able to meet the demand by obtaining loyal customers. The following table lists the 26 opportunity variables that were detected in the analysis.

\begin{tabular}{|r|l|}
\hline 1 & Market \\
\hline 2 & Faithful clients \\
\hline 3 & Demand \\
\hline 4 & Suppliers \\
\hline 5 & Government support \\
\hline 6 & Financing \\
\hline 7 & Technology \\
\hline 8 & Temporary sales \\
\hline 9 & Weak competition \\
\hline 10 & Trend \\
\hline 11 & New products \\
\hline 12 & Growth of prestige \\
\hline 13 & No competition \\
\hline 14 & Positioning \\
\hline 15 & Foreign customers \\
\hline 16 & Expansion abroad \\
\hline 17 & Expansion in national territory \\
\hline 18 & Variety of brands-products \\
\hline 19 & Technological advances \\
\hline 20 & Opening of a new branch \\
\hline 21 & Total coverage \\
\hline 22 & Location \\
\hline 23 & Different types of business contracts \\
\hline 24 & Easy access to the public \\
\hline 25 & Public campaigns \\
\hline 26 & Customer Increase \\
\hline
\end{tabular}

Table 2 Variables detected in opportunities

En Regarding weaknesses, 30 variables were detected, which are shown in Table 3.

The 5 variables with the most impact in both periods are detailed below.:
a) From the May-August 2018 period:
b) Bad business location,
c) Lack of publicity,
d) Bad organization of the company,

e) Local reduced and

f) Lack of parking.

See graphic 5.

From the period September-December 2018:
a) Lack of publicity,
b) Little personal,
c) Bad organization of the company,
d) Small premises,
e) Lack of maintenance and obsolete facilities.

See graphic 6.

The lack of knowledge about strategic planning is a consequence of the bad organization of the company that leads to the lack of strategies to correct the weaknesses. The following table lists the 30 variables of the weaknesses that were detected in the analysis.

\begin{tabular}{|r|l|}
\hline 1 & Lack of Advertising \\
\hline 2 & Little personal \\
\hline 3 & Bad organization of the company \\
\hline 4 & Reduced Local \\
\hline 5 & Lack of Maintenance and obsolete facilities \\
\hline 6 & Lack of parking \\
\hline 7 & Bad Organization of the Times \\
\hline 8 & Little variety of Products or Services and of poor quality. \\
\hline 9 & Lack of Training and ignorance of the branch \\
\hline 10 & Non motivated staff \\
\hline 11 & Bad business location \\
\hline 12 & Misuse of facilities and lack of hygiene. \\
\hline 13 & Collection terminal is missing \\
\hline 14 & Lack of Technology applied to business \\
\hline 15 & Shortage of merchandise \\
\hline 16 & Missing Security team for employees \\
\hline 17 & Little experience in the field \\
\hline 18 & Lack of budget \\
\hline 19 & There is no credit plan. \\
\hline 20 & Lack of Furniture \\
\hline 21 & No home delivery service \\
\hline 22 & They do not have their own premises \\
\hline 23 & Bad Work Environment \\
\hline 24 & There is no innovation \\
\hline 25 & Little clientele \\
\hline 26 & Low salaries \\
\hline 27 & Lack of Business Protection Insurance \\
\hline 28 & Lack of delivery vehicles \\
\hline 29 & The employees do not have social security. \\
\hline 30 & They are not registered in the SAT \\
\hline
\end{tabular}

Table 3 Variables detected in weaknesses

In the Threats quadrant 36 variables were detected, they are shown in table 4.

The 5 variables with the most impact in both periods are detailed below.. 
a) From the May-August 2018 period:

b) A lot of competition,

c) Unsafety,

d) Weather,

e) Price increase,

f) Damage to city streets.

See graphic 7 .

From the period September-December 2018:
a) A lot of competition,
b) Unsafety,
c) Increase in raw material prices,
d) Damage to city streets and
e) Weather.

See graphic 8 .

These threats reflect the lack of a situational diagnosis that PEST analysis (political, economic, social, technological) can help to know the external factors that weaken MSMEs. The following table lists the 36 threat variables that were detected in the analysis.

\begin{tabular}{r|l|}
\hline 1 & A lot of competition \\
\hline 2 & Unsafety \\
\hline 3 & Weather \\
\hline 4 & Price increase \\
\hline 5 & Damage to city streets \\
\hline 6 & seasons \\
\hline 7 & Lack of suppliers \\
\hline 8 & Taxes - increase \\
\hline 9 & Negative publicity \\
\hline 10 & Market Ignorance \\
\hline 11 & Similar products \\
\hline 12 & Loss of clients \\
\hline 13 & Devaluation \\
\hline 14 & Work accidents \\
\hline 15 & Internet sales \\
\hline 16 & Franchises \\
\hline 17 & Customer Mistrust \\
\hline 18 & Pests \\
\hline 19 & Noisy neighbors \\
\hline 20 & Expiration \\
\hline 21 & Equipment abuse by the client \\
\hline 22 & Dissatisfied customers \\
\hline 23 & Youth - inexperience \\
\hline 24 & Inflation \\
\hline 25 & Obstruction in ads \\
\hline 26 & Without licenses - legal problems \\
\hline 27 & Lack of vigilance \\
\hline 28 & Home service \\
\hline 29 & Poor quality production \\
\hline 30 & Beginning of the school year \\
\hline 31 & Misunderstanding of companies \\
\hline 32 & Threats \\
\hline 33 & There is no product culture \\
\hline 34 & Import and export restrictions \\
\hline 35 & Product transfer for delivery \\
\hline 36 & holidays \\
\hline
\end{tabular}

Table 4 Variables detected in threats
Once the needs of microentrepreneurs have been detected, the Educational Institution provides participatory advice with teachers and students to microentrepreneurs in the cities of Reynosa and Rio Bravo on basic issues such as accounting, marketing and administration to make material, human and financial resources efficient.

In addition, teachers and students carry out a Business Plan for a certain number of microentrepreneurs and they provide the necessary information to prepare it..

\begin{tabular}{|l|l|}
\hline Business plans \\
\hline May-August 2018 & 34 \\
\hline September-December 2018 & 47 \\
\hline
\end{tabular}

Table 5 Cantidad de planes de negocio

Finally, a "Guidance and Advice for your business" Forum is held where Government Dependencies and Banking and Financial Institutions and entrepreneurs are invited to transmit their experience.

Some participating units are:

$\begin{array}{ll}- & \text { HIS SIGN } \\ - & \text { TAMAULIPAS FUND } \\ - & \text { BANK INSTITUTIONS. } \\ - & \text { CANACINTRA } \\ - & \text { SECRETARIAT OF ECONOMY } \\ - & \text { CANACO } \\ - & \text { COPARMEX }\end{array}$

\section{References}

Arana, D. (31 de Enero de 2018). Pymes mexicanas, un panorama para 2018. Obtenido de https://www.forbes.com.mx: https://www.forbes.com.mx/pymes-mexicanasun-panorama-para-2018/

Ayala, V. M. (2018). LA COMPETITIVIDAD DE LAS PYMES EN MÉXICO: RETOS Y OPORTUNIDADES ANTE UN MUNDO GLOBALIZADO. Horizontes de la Contaduría en las Ciencias Sociales, 83-84.

INEGI. (2016). Esperanza de vida de los negocios en México. Obtenido de https://www.inegi.org.mx/temas/evnm/doc/evn _ent_fed.pdf 